\title{
READING LITERACY AND METACOGNITIVE STRATEGY FOR PREDICTING ACADEMIC ACHIEVEMENT
}

\author{
Siti Mahmudatul Banat dan Adi Cilik Pierewan \\ Universitas Negeri Yogyakarta \\ email: banat72.smb@gmail.com
}

\begin{abstract}
The importance of reading literacy is shown in the results of achievement among international countries. Reading literacy has not become a culture for most students. Some students have not used reading strategies to improve their understanding. This will affect the academic achievement. This expost facto research design aims to examine: (1) wether reading literacy can predict academic achievement in knowledge and skill, (2) wether metacognitive strategy can predict academic achievement in knowledge and skill, and (3) wether reading literacy and metacognitive strategy together can predict academic achievement on knowledge and skill. The population is 543 students of three pilot senior high schools of Curriculum 2013 in Kulon Progo. The sample is 359 students established using the Table of Isaac and Michael. The instrument used is a questionnaire. The result is as follows. Fisrt, reading literacy can predict academic achievement in knowledge, but it cannot predict academic achievement in skill. Second, metacognitive strategy can predict academic achievement in knowledge and skill. Thirth, reading literacy and metacognitive strategy simultaneously can predict academic achievement on knowledge and skill. Therefore literacy habituation and the use of metacognitive strategies are strongly recommended to improve academic achievement of knowledge and skills.
\end{abstract}

Keywords: academic achievement, knowledge, metacognitive strategy, reading literacy, skill

\section{LITERASI MEMBACA DAN STRATEGI METAKOGNITIF UNTUK MEMPREDIKSI PRESTASI AKADEMIK}

\begin{abstract}
Abstrak
Pentingnya literasi membaca ditunjukkan pada hasil prestasi di antara negera-negara internasional. Literasi membaca belum menjadi budaya pada sebagian besar siswa. Sebagian siswa belum menggunakan strategi membaca untuk meningkatkan pemahamannya. Hal ini akan berpengaruh terhadap prestasi akademiknya. Penelitian expost facto ini bertujuan untuk menguji : (1) apakah literasi membaca dapat memprediksi prestasi akademik pengetahuan dan keterampilan, (2) apakah strategi metakognitif dapat memprediksi prestasi akademik pengetahuan dan keterampilan, serta (3) literasi membaca dan strategi metakognitif secara bersama-sama dapat memprediksi prestasi akademik pengetahuan dan keterampilan. Populasi dalam penelitian ini adalah 543
\end{abstract}


siswa siswa kelas XI dari 3 SMA rintisan kurikulum 2013 di Kulon Progo. Sampel sejumlah 359 diambil dengan menggunakan tabel Isaac dan Michael. Alat ukur dengan menggunakan kuesioner. Hasil penelitian sebagai berikut. Pertama, literasi membaca dapat memprediksi prestasi akademik pengetahuan tetapi tidak terhadap prestasi akademik keterampilan. Kedua, strategi metakognitif dapat memprediksi prestasi akademik pengetahuan dan keterampilan. Ketiga, literasi membaca dan strategi metakognitif secara simultan dapat memprediksi prestasi akademik pengetahuan dan keterampilan. Oleh karena itu pembiasaan literasi membaca dan penggunaan strategi metakognitif sangat disarankan untuk meningkatkan prestasi akademik pengetahuan dan keterampilan.

Kata Kunci: prestasi akademik, pengetahuan, strategi metakognitif, literasi membaca, keterampilan

\section{INTRODUCTION}

Academic achievement is often related to learning achievement through a set of evaluation in education institutions or participation in evaluation activities in the institutions that manage educational evaluation. Gill, Timpane, \& Brewer (2001: 69) define academic achievement as measuring achievement through the progress in school, graduates, and the admission to higher education, as well as academic skill and knowledge. Ideally, the measurement of achievement evaluates not only the basic skill in reading and mathematics, but also the knowledge, cognitive skill, and wider creativity in a wider scope beginning from science up to fine arts. Farida (2017: 2-3) states that academic achievement is measured through evaluation.

In the Program of International Student Assessment (PISA) organized by the OECD get an overview of the achievements of Indonesian teenagers among international countries. The results of the PISA assessment, Indonesian students have experienced an increase in the three competencies tested. Indonesian teens in 2012 ranked 70 (OECD, 2012) and in 2015 ranked 64 out of 72 PISA participants (OECD, 2015). This illustrates the achievements of Indonesian students, but still below the median of other participating countries.

Academic achievement is obtained by undertaking several efforts. Some studies related to academic achievement describe a varieties of backgrounds that affect it. Pecorari et al. (2012) found that there is a strong relationship between reading and academic achievement. Smith, Black,\& Hooper (2017) state that metacognitive strategy with the self-regulation technique may form an effective basis for students to achieve academic successes.

Reading literacy for common people or reading for a non-expert is very important in human life as the basis for achieving science and everyday activities. It is stated in OECD (2009: 3 ) that adults are expected to use information in a complex way. Therefore, literacy is important not only for personality development, but also for a positive result of 
education, society, and economy. In reality, however, as reported in the research by Sari \& Pujiono (2017: 105) reading activities resulted more from assignments than from hobbies. The cons- traints are laziness, weak motivation, fatigue, lack of references in libraries, and lack of English references. According to research, reading activities of reading literacy do not become everyday life habit, but it is felt as an obligation because of assignments.

Reading for doing different kinds of activities and especially learning activities needs the effort to understand in order to be more effective. Some students are used to using varieties of ways or strategies to study more effectively. Learning by using a strategy has also been proved to be related to academic achievement. Hoewever, according to research by Schwonke (2015: 172) most students cannot manage their own learning automatically.

Based on the findings of the research by experts, there needs to be a study on reading literacy and cognitive strategy which can predict academic achievement. This kind of study is expected to become one of the problem solutions that can be used for improving academic achievement.

First, reading literacy. Reading literacy according to Marsh et al. (2006: 3) define reading literacy as the competence to understand and use the forms of written language which is needed by people and/or appreciated by individuals. Young readers can make meanings from different kinds of texts. They read for learning, for participating in reading communities, and for enjoyment. There- fore, according to Scribner in Britt, Rouet, \& Durik (2018: 1) reading literacy can be defined as social practices related to written symbols. In the post-industrial community, the use of printed media includes one's lifetime activities, from studying in school until getting ajob, communicating with friends and relatives, shopping on line, and participating in the community. From different definitions above, it can be concluded that reading literacy is how readers perceive meanings from written symbols or texts for everyday life necessities, both formally and informally.

In order to get of understanding of the process of reading literacy, reading participation is needed. Reading participation is to what extent someone performs reading especially his or her reading frequency. The Self-Determinant Theory (SDT) states that motivation is related to energy, direction, perseverance, and equality in all aspects of activities and intentions. Furthermore, SDT describes that the existence of intrinsic motivation is the tendency to discover new things and challenges, to expand and train one's working capacities, to explore and learn (Ryan \& Deci, 2000: 69-70).

The findings of the research by Gaoa et al. (2018) show that the improvement in reading skill can improve academic achievement. However, Bharuthram (2017: 54) in his research found the students' low motivation in reading, and they read only if there is external pressure. They find it difficult to read, and few of them apply a reading strategy. Another finding is that in this era reading has transformed from the printed format to the digital format (Kurata et al., 2016: 1). 
However, the finding of the research by Wu \& Peng (2016: 1) shows students' better reading literacy in printed environment.

Second, metacognitive strategy. Metacognitive strategy according to Block \& Israel (2005: 154) explain that a good reader uses a metacognitive strategy for thinking and controlling before, while, and after reading a text. In OECD (2009: 72) metacognitive strategy in general and reading strategy in particular are defined as mental or behavioural activities which help students to achieve their cognitive objective. From the various definitions above, it can be concluded that metacognitive strategy is how someone thinks about achieving his or her cognitive activities maximally.

Empirical data show that a strategy can help students improve perseverance and building the growth of success mindset affects academic performances (Polirstok, 2016). The application of metacognitive strategy has a positive impact on students' being more selfconfident with their autonomous learning (Sedhu, Ali, \& Harun, 2017). Research findings show that many teenager students are not equipped with internal resources and knowledge to involve in metacognitive processes (Smith et al., 2017).

Based on the description above, reading literacy and using metacognitive strategies is expected to improve academic achievement. Therefore in this study the question is whether reading literacy, metacognitive strategies, or both can predict academic achievement in knowledge and skills?

\section{METHOD}

This study is quantitative research with the expost facto approach. It aims to reveal reading literacy and metacognitive strategy for predicting the academic achievement of the students of senior high schools piloting Curriculum 2013 in Kulon Progo, the Special Territory of Yogyakarta, Indonesia. The research population is 543 grade 11 students of three senior high schools. The sample is 359 students established using Isaac and Michael Table.

This research used a standardized non-test instrument adapted from PISA 2009 questionnaire, which was used to reveal the achievement background of PISA 2009 evaluation. The questionnaire was used to reveal the background of the achievement of the students of the senior high schools which become the pilot schools of Curriculum 2013 in Kulon Progo. The questionnaire is assured to be applied internationally because it involved experts, by considering the context of culture and curriculum of the member countries of OECD. The experts have strong measurement properties, and put the emphasis on originality and validity of education. The questionnaire expert group is chaired by Jaap Scheerens from the University of Twente in Netherland. However, validity testing was still conducted through expert judgement, Pearson Correlation and reliability testing by using Cronbach's Alpha.

The expert judging the PISA questionnaire is Dra. Pangesti Wiedarti, M.Appl. Ling., Ph.D. who has expertise in applied and descriptive linguistics. She is also the 
chairperson of the Taskforce for National School Literacy Movement. The result of the validation was feasible to try out with revision on the display. Later, the instrument was tried out using a sample consisting of 60 students of natural science and social science classes. The result of the tryout was validated using Pearson Correlation. The result of the validation of reading literacy variable showed that four items were invalid because the significance value was higher than 0.05 . In variable metacognitive strategy, all items were valid because the significance value was less than 0.05 . The reliability testing using Cronbach's Alpha resulted in the reliability value of 0.791 for the variable of reading literacy and 0.742 for the variable of metacognitive strategy. Those reliability values were higher than 0.600 , so that it can be concluded that the questionnaire is reliable.
The data were anlyzed quantitatively using the SPSS 22 Program. The result of the null hypothesis (H0) is (1) reading literacy has a positive effect on academic achievement in knowledge but it has a negative effect on the academic achievement in skill; (2) metacognitive strategy has a positive effect on academic achievement in knowledge and skill; (3) reading literacy and metacognitive strategy together have a positive effect on academic achievement in knowledge and skill.

Reading literacy and metacognitive strategy are measured by using PISA 2009 questionnaire. The variable of reading literacy consists of five questions. Each question consists of some subquestions as the answers. The first question (about how much time do you usually spend reading enjoyment?) consists of five alternative answer questions with interval scales. The second question (how

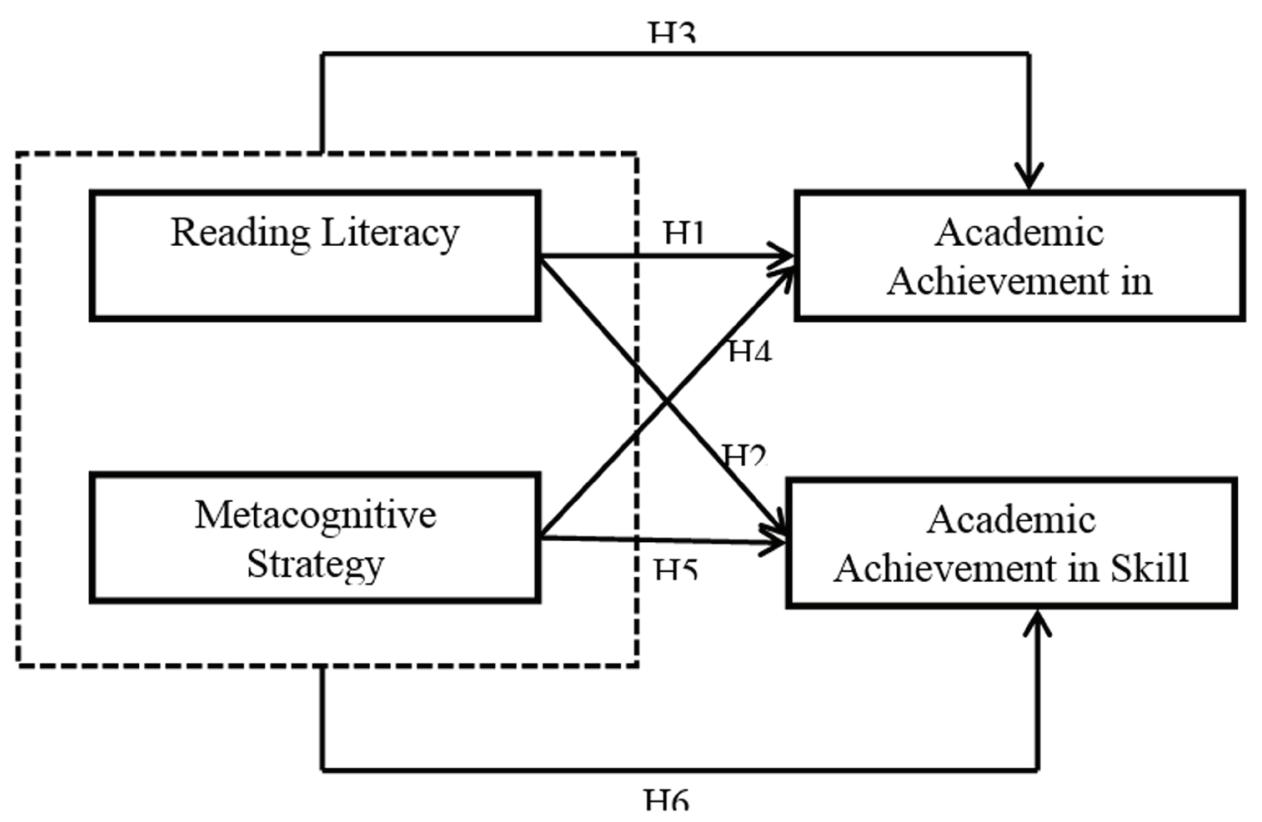

Figure 1. Conceptual Model of the Study 
much do you agree or disagree with these statements about reading?) consists of 11 statements as the alternative answers which are measured with the four-point Likert scale. The third question (how often do you read these materials because you want to?) consists of three statements which are measured with the five-point Likert scale. The fourth question (how often are you involved in the following reading activities?) consists of five statements as alternative answers which are measured with an interval scale. The fifth question (when you are studying, how often do you do the following?) consists of 13 statements as the alternative answers which are measured with the four-point Likert scale. In the variable of metacognitive strategy, there is one question (how do you rate the usefulness of the following strategies for understanding and memorising the text?) with six statements as the alternative answers which are measured with Turstone scale.

The variable of academic achievement is measured by using the end-of-semester cumulative score reported by the teacher in the form of a rapport book. The result of the research by Stephan \& Schaban (2002), Singh \& Malik (2016: 176) reported that the majority of researchers in the world apply the cummulative achievement index to evaluate students' performance. The rapport book scores which are used are the average scores in knowledge and skill in all school subjects.

\section{RESULTS AND DISCUSSION Results}

The research data were analyzed quantitatively using the multiple linear regression analysis by using SPSS version
22 for Windows to investigate reading literacy and metacognitive strategy to predict academic achievement. The result of the analysis is shown in the following table.

Table 1. Effect of reading literacy on academic achievement in knowledge

\begin{tabular}{lr}
\hline $\mathrm{N}$ & 359 \\
$\mathrm{t}_{\text {count }}$ & 4.507 \\
$\mathrm{t}_{\text {table }} .05$ & 1.967 \\
\hline
\end{tabular}

Based on the table containing the result of the analysis of the t-test using the SPSS above, the significance value is lower than 0.05 , which means that there is a significant effect of variable reading literacy on variable academic achievement in knowledge. In addition, the value of t-count $>\mathrm{t}$ table $(4.507>1.967)$, so that Ho is rejected. Therefore, it can be stated that reading literacy variable partially affects academic achievement in knowledge. The effect of variable reading literacy on academic achievement in knowledge is positive because the value of t-count is positive (4.507). This means that if reading literacy increases, academic achievement in knowledge will also increase.

Table 2. Effect of metacognitive strategy on academic achievement in knowledge

\begin{tabular}{lr}
\hline $\mathrm{N}$ & 359 \\
$\mathrm{t}_{\text {count }}$ & 4.279 \\
$\mathrm{t}_{\text {table }} .05$ & 1.967 \\
\hline
\end{tabular}

Based on the table containing the result of the analysis of the t-test using the SPSS above, the significance value is lower than 0.05 , which means that there is a significant effect of variable metacognitive 
strategy on variable academic achievement in knowledge. Variable metacognitive strategy partially affects variable academic achievement in knowledge. In addition, the value of t-count $>\mathrm{t}$ table (4.279 > 1.967), so that Ho is rejected. The effect of variable metacognitive strategy on achievement in knowledge is positive. This means that if metacognitive strategy increases, academic achievement in knowledge will also increase.

Table 3. Effect of reading literacy and metacognitive strategy on academic achievement in knowledge

\begin{tabular}{lc}
$\mathrm{N}$ & 359 \\
$\mathrm{R}$ & $.355^{\mathrm{a}}$ \\
$\mathrm{R} 2$ & .126 \\
\hline
\end{tabular}

The table above shows that R-square $\left(r^{2}\right)$ has the value of 0.126 , which means that the variables of reading literacy and metacognitive strategy can predict academic achievement in knowledge. However, the prediction is weak because it is close to zero. The result of R-square $\left(r^{2}\right)$ also describes that reading literacy and metacognitive strategy can describe 12.6\% variation on academic achievement. In other words, $12.6 \%$ of the change occurs to academic achievement in knowledge and the rest $87.4 \%$ is described by the factors other than the two variables.

Table 4. Effect of reading literacy on academic achievement in skill

\begin{tabular}{lr}
\hline $\mathrm{N}$ & 359 \\
$\mathrm{t}_{\text {count }}$ & 1.024 \\
$\mathrm{t}_{\text {table }} .05$ & 1.967 \\
\hline
\end{tabular}

Based on the table containing the result of the analysis of the t-test using the SPSS above, the significance value is higher than 0.05 , which means that there is no significant effect of variable reading literacy on variable academic achievement skill. In addition, the value of $\mathrm{t}$-count $<\mathrm{t}$ table $(1.024<1.967)$, so that $\mathrm{Ho}$ is accepted. Therefore, it can be stated that reading literacy variable partially does not affect academic achievement in skill.

Table 5. Effect of metacognitive strategy on academic achievement in skill

\begin{tabular}{lrr}
\hline \multicolumn{3}{c}{ Effect of $\mathbf{X} 1$ on $\mathbf{Y 2}$} \\
\hline $\mathrm{N}$ & 359 \\
$\mathrm{t}_{\text {count }}$ & & 3.403 \\
$\mathrm{t}_{\text {table }} .05$ & & 1.967 \\
\hline
\end{tabular}

Based on the table containing the result of the analysis of the t-test using the SPSS above, the significance value is lower than 0.05 , which means that there is a significant effect of variable metacognitive strategy on variable academic achievement in skill. In addition, the value of $t$-count $>t$ table $(3.403>1.967)$. Therefore, it can be stated that metacognitive strategy partially affects academic achievement in skill. The effect of variable metacognitive strategy on academic achievement in skill is positive because the value of t-count is positive. This means that the increase in metacognitive strategy will be followed by the increase in academic achievement in skill.

Table 6. Effect of reading literacy and metacognitive strategy on academic achievement in skill

\begin{tabular}{lr}
\hline $\mathrm{N}$ & 359 \\
$\mathrm{R}$ & $.203^{\mathrm{a}}$ \\
$\mathrm{R} 2$ & .041 \\
\hline
\end{tabular}


The table above shows that R-square $\left(\mathrm{r}^{2}\right)$ has the value of 0.041 , which means that reading literacy and metacognitive strategy can predict academic achievement in skill. However, the prediction is weak because it is close to zero (0). The value of $\mathrm{r}^{2}$ also describes that reading literacy and metacognitive strategy can describe $4.1 \%$ of the variance of academic achievement in skill. In other words, $4.1 \%$ of the change occurs to academic achievement in skill and the rest of $95 \%$ is described by the factors other than the two variables.

\section{Discussion}

This research aims to investigate whether or not reading literacy and metacognitive strategy can predict the academic achievement in both knowledge and skill of the students of the senior high schools piloting Curriculum 2013 in Kulon Progo. The findings show that reading literacy and metacognitive strategy can predict the academic achievement in knowledge and skill of the students.

The effect of variable reading literacy on academic achievement in knowledge is positive because the value of t-count is positive (4.507). This means that if reading literacy increases, academic achievement in knowledge will also increase. Reading literacy is very important because it is the core of education. In order to master and develop knowledge, everyone needs the reading literacy competence. With reading literacy, we can get much important information. This information can be obtained in the form of both printed texts and electronic texts, written or spoken, and in continuous, discontinuous, or the mixture of the two forms. Reading literacy competence can be obtained through perse- verance, persistence, and motivation. The mastery of knowledge obtained through reading literacy will improve academic achievement.

Based on the result of this research, academic achievement in knowledge will increase if reading literacy increases. Learning knowledge needs reading literacy competence. Therefore, if reading competence increases, academic achievement will also increase. This finding is supported by Whitten, Labby, \& Sullivan (2016: 48) who conclude that the students who read for enjoyment have a higher average score than their friends who do not read the measured field texts. This means that the students who read the literature of their own choice for enjoyment will get a higher score in English, mathematics, science, and history than those who do not read. Therefore, the involvement in reading literacy with intrinsic motivation becomes the predictor of academic achievement. This is in line with the finding of the research by Trevino \& DeFreitas (2014) that there is a relationship between intrinsic motivation and academic achievement and it becomes an important factor in academic successes. Intrinsic motivation also has a positive effect on a higher passing level.

Based on the finding of this research, reading literacy becomes very important for human's life in order to participate in the activities in the community. This is supported by the finding that reading literacy is the basis for achievement in other fields of study in the education system. Reading literacy is also a prerequisite for successful participation in some areas of adults' life (Cunningham \& Stanovich, 1998; Smith, Mikulecky, Kibby, \& Dreher, 2000 in OECD 2009). 
The result of the hypothesis testing proves that the variable of metacognitive strategy partially affects academic achievement in knowledge. This is proved by the significance value of lower than 0.05. Likewise, the t-count is $>\mathrm{t}$ table (4.279 > 1.967), so that the Ho is rejected. The result of the hypothesis testing also proves that the effect of variable metacognitive strategy on academic achievemen ini knowledge is 4.279 or it can be said that the $\mathrm{t}$-count is positive. This means that if metacognitive strategy increases, academic achievement in knowledge will also increase. This is in line with the finding of the research by Ohtani \& Hisasaka (2018) that metacognition is an effective predictor of academic achievement, which shows the importance of metacognition in education.

Academic successes need learning processes by using various ways and strategies. The metacognitive strategy is how one activates one's cognition to achieve the understanding of the knowledge one is learning. Various ways or strategies can be in the form of memorizing, summarizing, reading by marking the reading materials, reading aloud, and discussing with friends. These various strategies can improve academic achievement.

The metacognitive strategy in a broader sense is students' ability to manage learning techniques in line with the knowledge they expect to achieve. According to the result of the research by Marsh et al. (2006: 2), the students who are good at managing their own learning are able to identify or distinguish a suitable objective, and able to choose the suitable approach to achieving their objectives, so that they will achieve their objectives. In a more emphatic manner, Säälik, Nissinen, \& Malin (2015: 36) state that metacognitive learning strategy is useful to improvelearning achievement significantly. However, the statistical data of this study show that the metacognitive strategy of the students of senior high school piloting Curriculum 2013 is low, and therefore, they need to be encouraged to improve their ability to use the metacognitive strategy in their study.

Based on the result of the F-test, the significance value is lower than 0.05 , which means that reading literacy variable and metacognitive strategy together affect the variable of academic achievement in knowledge. This is also proved by the F-count of $>$ F-table $(25.660>3.021)$ and therefore Ho is rejected. Academic achievement is the students' competence, ability or the achievement which accumulates from time to time because of learning processes. From the learning processes, there are various internal and external affecting factors. Reading literacy or reading (for common people) is a very important factor. This is because reading literacy becomes the basis for mastering other knowledge. Reading literacy itself becomes a stronger affecting factor when accompanied with the will to improve learning achievement by using reading strategies. Metacognitive strategy is one of the factors which also affects reading quality so that eventually it will affect the result of teaching processes, which is called academic achievement. The result of the research by Djudin (2017: 124) states that metacognitive strategy can improve indepth understanding of textbooks and even to discover solution to a 
problem. This is in line with the finding or the research by Usman, Aziz, \& Absida (2017: 435) that metacognitive strategy can improve students' understanding of reading materials and it can even improve students' knowledge. In line with other research findings, the finding of the research by Channa et al. (2015) states that in order to understand reading texts, students need to use strategies. The use of metacognitive strategy is for the purpose of improving reading skill so that students' understanding of reading texts is better according to their needs.

The result of the regression analysis shows that the value of the R-square $\left(\mathrm{r}^{2}\right)$ is 0.126 . This shows that the variable of reading literacy and metacognitive strategy can describe $13 \%$ of the variance of academic achievement in knowledge. In other words, $13 \%$ of the change occurs to academic achievement in knowledge, while the rest $87 \%$ is described by the factors other than the two variables. The result of the hypothesis testing shows the significance value of more than 0.05 , which means that there is no significant effect of variable reading literacy on academic achievement in skill. In addition, the value of the t-count $<\mathrm{t}$ table $(1.024<$ 1.967), and therefore the Ho is accepted. Therefore, it can be stated that the variable of reading literacy partially affects academic achievement in skill.

The academic achievement in skill which is realized in the form of the score of skill is obtained from the result of the application of the knowledge that the students have got. For this reason, reading literacy has more effect on the academic achievement in knowledge than the academic achievement in skill. This shows that this research puts more emphasis on literacy in reading texts, both printed and electronic texts. This literacy is based on the Dual Coding Theory (DCT) which is verbal literacy (Sadoski, McTigue, \& Paivio, 2012). This literacy is generally used in learning knowledge, while skill is the practice of knowledge. Hutapea \& Thoha (2008: 31) state that knowledge is obtained only through listening and watching, while skill must be proved by its owner by showing the ability to perform a task.

In the 2013 curriculum, learning skills contain abstract and concrete skills. Abstract skills further develop mental skills, such as the skill of presenting, processing reasoning, and creating. This skill is a thinking skill. Concrete skills tend to develop which are motoric skills. These physical motor skills are the ability to use tools starting from perception, passivity, imitation, familiarizing proficient movements, becoming natural movements, becoming an orional movement (Syarifudin,: 40-42)

From the above exposition that reading literacy has no effect on academic achievement in skill because reading literacy is the activity of looking at sentences (texts). From the activity of looking, the sentences or texts can be understood and valued. Therefore, academic achievement in knowledge is the result of the ability measurement using the mind and creativity to change or make something more meaningful. Furthermore, after understanding and giving meaning, one will perform a task in accordance with the level of the understanding and valuing. This is in 
line with what has been put forward by At- Taubany \& Suseno (2017: 136). Teaching and learning processes start from the mastery of knowledge competence and followed by the mastery of skill competence.

Reporting academic achievement skills consists of subjects with concrete skills and abstract skills. Subjects use abstract skills such as social sciences and natural sciences, while subjects that use concrete skills are subjects of sports, arts and crafts. Abstract skills tend to still require reading literacy, while concrete skills tend to require fewer literacy skills to read. Thus reading literacy cannot predict academic achievement skills because ability in the realm of skills does not all require high literacy literacy skills.

\section{CONCLUSION}

Based on the data analysis and the previous discussion, six conclusions can be drawn from this research. They are as follows: reading literacy can predict academic achievement in knowledge, which means that the higher the reading literacy, the higher the academic achievement in knowledge will be; metacognitive strategy can predict academic achievement in knowledge, which means that the higher the metacognitive strategy, the higher the academic achievement in knowledge will be; reading literacy and metacognitive strategy together can predict academic achievement in knowledge, which means that the higher the reading literacy, the higher the metacognitive strategy will be; reading literacy cannot predict academic achievement in skill, which means the higher reading literacy cannot predict academic achievement in skill; meta- cognitive strategy can predict academic achievement in skill, which means the higher metacognitive strategy, the higher academic achievement in skill will be; and reading literacy and metacognitive strategy together can predict academic achievement in skill, which means the higher the reading literacy and metacognitive strategy, the higher the academic achievement in skill will be.

The results of this study indicate that reading literacy and metacognitive strategies have a significant influence on academic achievement on knowledge and skills. Therefore it is very important to increase the quantity and quality of reading. The habit of reading is an effective step to make it happen.

\section{ACKNOWLEDGEMENTS}

We would like to thank our peers, colleagues, and the respondent students of Senior High School 1 Sentolo, Senior High School 1 Wates, and Senior High School 2 Wates.

\section{REFERENCES}

At- Taubany \& Suseno, H. (2017). Desain Pengembangan Kurikulum 2013 di Madrasah. Depok : Kencana

Bharuthram, S. (2017). The Reading Habits and Practices of Undergraduate Students at A Higher Education Institution in South Africa: A Case Study. The Independent Journal of Teaching and Learning, 12 (1).

Block, C. C. \& Israel, S. E. (2005). Reading First and Beyond. California : Corwin Press

Britt, A. M., Rouet, J. S., \& Durik, A (2018). Literacy Beyond Text 
Comprehension (A theory of Purposefull Reading). New York : Routledge

Channa, M. A., Nordin, Z. S., Siming, I.

A., Chandio, A. A. \& Koondher, M.

A. (2015). Developing Reading Comprehension Through Metacognitive Strategies: A Review of Previous Studies. English Language Teaching, 8 (8). http://dx.doi.org/ 10.5539/elt.v8n8p181

Djudin, T. (2017) Using Metacognitive Strategies to Improve Reading Comprehension and Solve a Word Problem. Journal of Education, Teaching and Learning, 2(1) 124-129. DOI: $10.26737 /$ jetl.v2i1.151

Farida, I. (2017). Evaluasi Pembelajaran. Bandung: PT Remaja Rosdakarya.

Gill.P., Timpane P. M., Ross K. E.,\& Brewer D. J. (2001) Rhetoric vs. Reality. What We Know and What We Need To Know About Vouchers and Charter Schools. New York : RAND Corporation.

Gaoa,Q., Wanga,H., Mob, D., Shia, Y , Kennyb, K., \& Rozelle, S. (2018). Can Reading Programs Improve Reading Skills and Academic Performance in Rural China? China Economic Review. https://doi.org/ 10.1016/j.chieco.2018.07.001.

Hutapea, P. \& Thoha, N (2008). Kompetensi Plus. Teori, Desain, Kasus, dan Penerapan Untuk HR dan Organisasi yang Dinamins. Jakarta : PT Gramedia Pustakan Utama.

Kurata K., Ishita E, Miyata Y, \& Minami Y. (2016). Print or Digital? Reading Behavior and Preferences in Japan. Journal of the association for information science and technology, 00(00):00-00. DOI: $10.1002 /$ asi.23712
Marsh, H. W., Hau, K., Artelt, C., Baumert, J., \& Peschar, J. L. (2006) OECD's Brief Self-Report Measure of Educational Psychology's Most Useful Affective Constructs: CrossCultural, Psychometric Comparisons Across 25 Countr. International Journal of Testing, 6(4), 311-360. DOI: 10.1207/s15327574ijt0604.

OECD (2009). PISA 2009 Assessment Framework Key Competencies in Reading, Mathematics And Science. The OECD Secretariat : The Secretary-General of the OECD.

Pecorari, D., Shaw, P., Irvine, A., Malmstrom, H. \& Mezek, S. (2012). Reading In Tertiary Education: Undergraduate Student Practices and Attitudes. Quality in Higher Education, 18(2), 235-256. http:// dx.doi.org/10.1080/13538322.2012 .706464

PISA 2012 Results in Focus: What 15-Year-Olds Know and 42 What They Can Do With What They Know (C) OECD 2014.

Polirstok, S. (2017). Strategies to Improve Academic Ahievement in Secondary School Students: Perspectives On Grit And Mindset. Journals.sagepub. com/home/sgo. DOI: 10.1177/ 2158244017745111

Results from PISA 2015. (C) OECD 2016 Ryan, M. R. \& Deci, E. L. (2000) SelfDetermination Theory and The Facilitation of Intrinsic Motivation, Social Development, and WellBeing. The American Psychological Association, Inc, 55(1), 68-78 DOI: 10.1037110003-066X.55.1.68.

Sari, E. S. \& Pujiono, S. (2017). Budaya Literasi di Kalangan Mahasiswa 
FBS UNY. Litera, 16(1), 105-113. DOI: $10.21831 / 1$ tr.v16i1.14254

Säälik, U., Nissinen, K. \& Malin, A (2015). Learning Strategies Explaining Differences in Reading Proficiency. Findings of Nordic and Baltic Countries in PISA 2009. Learning and Individual Differences, 42. 36-43. https://doi.org/10.1016/j. lindif.2015.08.025

Sadoski, M. , McTigue, E. M. \& Paivio, A. (2012). A Dual Coding Theoretical Model of Decoding in Reading: Subsuming the Laberge and Samuels Model. Reading Psychology. 33:465-496. http://dx. doi.org/10.1080/02702711.2011.55 7330

Schwonke, R. (2015). Metacognitive Load-Useful, or Extraneous Concept? Metacognitive And Self-Regulatory Demands in Computer-Based Learning. Educational Technology \& Society, 18 (4), 172-184.. Retrieved from https: / / creativecommons.org/ licenses/by-nc-nd/3.0/

Sedhu, D.S., Ali, S.M., Harun, H. (2017). The Use of Metacognitive Strategies by ESL Tertiary Learners in Learning IELTS Listening Course. International Journal of English Language and Literature Studies, 6(1), 11-24. DOI: 10.18488/ journal.23.2017.61.11.24

Singh, S. P. \& Malik, S. (2016). Research Paper Factors Affecting Academic Performance of Students. Indian
Journal Research. 5 (4). https://www. $\mathrm{r}$ e s e a r c h g a t e. n e t / publication/301324970

Smith A.K., Black S, Hooper, L.M., (2017). Metacognitive Knowledge, Skills, And Awareness: A Possible Solution To Enhancing Academic Achievement In African American Adolescents. Urban Education 15(1). DOI: $10.1177 / 0042085917714511$

Trevino, N. N. \& DeFreitas, S. T. (2014). The Relationship Between Intrinsic Motivation and Academic Achievement for First Generation Latino College Students. Social Psychology of Education. DOI: 10.1007/s11218013-9245-3.

Usman, B., Aziz, Z. A. \& Absida, N. R. (2017) Improving Reading Comprehension Using Metacognitive Strategies. English Education Journal, 8(4), 425-438, E-ISSN: 2085-3750.

Whitten, C., Labby, S., \& Sullivan, S. L. The impact of Pleasure Reading on Academic Success. (2016) The Journal of Multidisciplinary Graduate Research, 2(4), 48-64.

Wu, J. Y. \& Peng, Y. C. (2016). The Modality Effect on Reading Literacy: Perspectives From Students' Online Reading Habits, Cognitive and Metacognitive Strategies, and Web Navigation Skills Across Regions. Interactive Learning Environments. http://dx.doi.org/10.1080/104948 20.2016.1224251. 